\title{
EKSISTENSI BERLAKUNYA PENCABUTAN HAK ATAS TANAH SETELAH BERLAKUNYA UNDANG-UNDANG NOMOR 2 TAHUN 2012
}

\author{
Urip Santoso \\ Dosen Hukum Agraria Fakultas Hukum Universitas Airlangga \\ E-mail: urip_sts@yahoo.com
}

\begin{abstract}
ABSTRAK
Perolehan hak atas tanah untuk kepentingan umum pada mulanya ditempuh melalui pencabutan hak atas tanah yang diatur dalam Pasal 18 Undang-Undang No. 5 Tahun 1960. Dalam perkembangannya, perolehan hak atas tanah untuk kepentingan umum ditempuh melalui pengadaan tanah untuk kepentingan umum yang diatur dalam Undang-Undang No. 2 Tahun 2012. Secara normatif, pencabutan hak atas tanah masih berlaku disebabkan oleh undang-undangnya belum diganti dengan undang-undang yang baru. Namun, secara empiris, yang diatur dalam Undang-Undang No. 2 Tahun 2012. Secara normatif, pencabutan hak atas tanah tidak dilaksanakan disebabkan oleh adanya undang-undang yang mengatur perolehan tanah untuk kepentingan umum.
\end{abstract}

Kata Kunci: pencabutan hak, pengadaan tanah, kepentingan umum.

\section{ABSTRACT}

Acquisition of land for public purposes initially pursued through the revocation of land rights under Article 18 of Law No. 5 of 1960. In its development, the acquisition of land for public purposes pursued through the provision of land for public purposes stipulated in Law No. 2 Year 2012. In normative, revocation of land rights is still valid caused by its laws have not been replaced by the new Act. In the other hand, empirically, revocation of land rights is not implemented due to the lack of legislation governing the acquisition of land for public purposes.

Keywords: withdrawal rights, land acquisition, public interest.

\section{PENDAHULUAN}

Salah satu asas yang ditetapkan dalam UndangUndang No. 5 Tahun 1960 tentang Peraturan Dasar Pokok-pokok Agraria, atau lebih dikenal dengan sebutan Undang-Undang Pokok Agraria (UUPA), adalah semua hak atas tanah mempunyai fungsi sosial. Asas semua hak atas tanah mempunyai fungsi sosial ditetapkan dalam Pasal 6 Undang-Undang No. 5 Tahun 1960. Oleh karena dalam rumusan Pasal 6 Undang-Undang No. 5 Tahun 1960 ditetapkan semua hak atas tanah mempunyai fungsi sosial, maka hak atas tanah mempunyai fungsi sosial tidak hanya Hak Milik, tetapi juga Hak Guna Usaha, Hak Guna Bangunan, Hak Pakai, dan Hak Sewa Untuk Bangunan.

Ketentuan mengenai semua hak atas tanah mempunyai fungsi sosial yaitu: pertama, Hak atas tanah apapun yang ada pada seseorang, tidaklah dapat dibenarkan bahwa tanahnya itu digunakan atau tidak digunakan semata-mata untuk kepentingan pribadinya, apalagi kalau hal itu merugikan masyarakat; kedua, Penggunaan tanah itu harus disesuaikan dengan keadaan dan sifat haknya, hingga bermanfaat baik bagi kesejahteraan dan kebahagiaan yang mempunyainya maupun bagi masyarakat dan negara; ketiga,Kepentingan perseorangan tidak akan terdesak sama sekali oleh kepentingan umum (masyarakat). UUPA memperhatikan pula kepentingan perseorangan. Kepentingan masyarakat dan kepentingan perseorangan haruslah saling mengimbangi, hingga tercapai tujuan pokok, yaitu kemakmuran, keadilan, dan kebahagiaan bagi rakyat seluruhnya; keempat, Tanah harus dipelihara baik-baik agar bertambah kesuburan serta dicegah kerusakannya. Kewajiban memelihara ini tidak saja dibebankan kepada pemegang haknya, melainkan menjadi beban pula bagi setiap orang, badan hukum, 
atau instansi yang memiliki suatu hubungan hukum dengan tanah itu. ${ }^{1}$

Asas semua hak atas tanah mempunyai fungsi sosial diimplementasikan dalam Pasal 18 UndangUndang No. 5 Tahun 1960 menegaskan, untuk kepentingan umum, termasuk kepentingan bangsa dan negara serta kepentingan bersama dari rakyat, hak-hak atas tanah dapat dicabut, dengan memberikan ganti kerugian yang layak dan menurut cara yang diatur dengan undang-undang. Berdasarkan ketentuan Pasal 18 Undang-Undang No. 5 Tahun 1960, hak-hak atas tanah dapat dicabut untuk kepentingan umum, termasuk kepentingan bangsa dan negara serta kepentingan bersama dari rakyat dengan pemberian ganti kerugian yang layak menurut cara dapat dicabut, dengan memberikan ganti kerugian yang layak dan menurut cara yang diatur dengan undang-undang.

Undang-undang yang melaksanakan ketentuan Pasal 18 Undang-Undang No. 5 Tahun 1960, adalah Undang-Undang No. 20 Tahun 1961 tentang Pencabutan Hak-hak Atas Tanah dan Benda-benda Yang Ada di Atasnya. Berdasarkan Pasal 18 UndangUndang No. 5 Tahun 1960 juncto Undang-Undang No. 20 Tahun 1961, perolehan hak atas tanah untuk kepentingan umum ditempuh melalui pencabutan hak atas tanah, dengan memberikan ganti kerugian yang layak kepada pemegang hak atas tanah yang terkena pencabutan hak atas tanah. Ada dua undangundang yang mengatur perolehan hak atas tanah untuk kepentingan umum, yaitu Undang-Undang No. 20 Tahun 1961 yang mengatur pencabutan hak atas tanah, dan Undang-Undang No. 2 Tahun 2012 yang mengatur pengadaan tanah bagi pelaksanaan pembangunan untuk kepentingan umum.

\section{PERUMUSAN MASALAH}

Dari uraian pendahuluan di atas dikaji permasalahan yang dirumuskan, yaitu bagaimanakah eksistensi Undang-Undang No. 20 Tahun 1961 dengan disahkannya Undang-Undang No. 2 Tahun 2012 yang mengatur perolehan hak atas tanah untuk kepentingan umum.

\section{METODE PENELITIAN}

Tipe penelitian pada penulisan ini adalah penelitian normatif dengan pendekatan masalah

\footnotetext{
1 Penjabaran Penjelasan Umum Undang-Undang No. 5 Tahun 1960 angka II nomor (4).
}

statute approach. Peraturan perundang-undangan yang dikaji adalah Undang-Undang No. 2 Tahun 2012 tentang Pengadaan Tanah Bagi Pelaksanaan Pembangunan Untuk Kepentingan Umum; UndangUndang No. 2 Tahun 2012 dilaksanakan oleh Peraturan Presiden No. 71 Tahun 2012 tentang Penyelenggaraan Pengadaan Tanah Bagi Pelaksanaan Pembangunan Untuk Kepentingan Umum; Peraturan Presiden No. 71 Tahun 2012 diubah oleh Peraturan Presiden No. 148 Tahun 2015 tentang Perubahan Keempat Peraturan Presiden Nomor 71 Tahun 2012 tentang Penyelenggaraan Pengadaan Tanah Bagi Pelaksanaan Pembangunan Untuk Kepentingan Umum.

\section{PEMBAHASAN \\ Pencabutan Hak Atas Tanah}

Penggunaan tanah untuk kepentingan umum merupakan implementasi dari asas hak atas tanah mempunyai fungsi sosial sebagaimana ditetapkan dalam Pasal 6 Undang-Undang No. 5 Tahun 1960. Dalam menggunakan tanah harus mengedepankan atau mengutamakan kepentingan umum, termasuk kepentingan bangsa dan negara serta kepentingan bersama dari rakyat daripada kepentingan pribadinya. Apabila kepentingan umum menghendaki diambilnya hak atas tanah, maka pemegang hak atas tanah atau melepaskan hak atas tanah dengan pemberian ganti kerugian yang layak melalui mekanisme pencabutan hak atas tanah. ${ }^{2}$

Pencabutan hak atas tanah diatur dalam Pasal 18 Undang-Undang No. 5 Tahun 1960 menegaskan bahwa, Untuk kepentingan umum, termasuk kepentingan bangsa dan negara serta kepentingan bersama dari rakyat, hak-hak atas tanah dapat dicabut, dengan memberikan ganti kerugian yang layak dan menurut cara yang diatur dengan Undang-Undang. Ketentuan dalam Pasal 18 Undang-Undang No. 5 Tahun 1960 menegaskan bahwa ruang lingkup untuk kepentingan umum adalah termasuk kepentingan bangsa dan negara serta kepentingan bersama dari rakyat, dan Hak-hak atas tanah dapat dicabut; serta Pemberian ganti kerugian yang layak; Pencabutan hak atas tanah diatur dengan Undang-Undang.

Undang-Undang yang melaksanakan ketentuan Pasal 18 Undang-Undang No. 5 Tahun 1960,

\footnotetext{
${ }^{2}$ Urip Santoso, Hukum Agraria Kajian Komprehensif, Kencana Prenada Media, Jakarta, 2014, h. 58-59.
} 
adalah Undang-Undang No. 20 Tahun 1961 tentang Pencabutan Hak-hak Atas Tanah dan Benda-benda Yang Ada di Atasnya. Undang-Undang No. 20 Tahun 1961dilaksanakan oleh Peraturan Pemerintah No. 39 Tahun 1973 tentang Acara Penetapan Ganti Kerugian Oleh Pengadilan Tinggi Sehubungan Dengan Pencabutan Hak-hak Atas Tanah dan Benda-benda Yang Ada di Atasnya, dan Instruksi Presiden No. 9 Tahun 1973 tentang Pedoman-pedoman Pelaksanaan Pencabutan Hak-hak Atas Tanah dan Benda-benda Yang Ada di Atasnya.

Dalam pelaksanaannya, Undang-Undang No. 20 Tahun 1961 mempunyai 2 (dua) fungsi, yaitu: pertama, Sebagai landasan (dasar) hukum bagi pemerintah dan perusahaan swasta untuk memperoleh tanah yang diperlukan guna menyelenggarakan kepentingan umum; kedua, Sebagai jaminan perlindungan hukum pemegang hak atas tanah untuk mendapatkan perlindungan hukum dalam pemberian ganti kerugian yang layak. ${ }^{3}$

Pencabutan hak atas tanah merupakan salah satu faktor penyebab hapusnya hak atas tanah dan berakibat hak atas tanah kembali menjadi tanah negara atau tanah yang dikuasai langsung oleh negara. Ketentuan dalam Undang-Undang No. 5 Tahun 1960 yang menetapkan bahwa hak atas tanah hapus karena pencabutan hak atas tanah, yaitu Pasal 27 huruf (a) angka 1 untuk Hak Milik, Pasal Pasal 34 huruf (d) untuk Hak Guna Usaha, dan Pasal 40 huruf (d) untuk Hak Guna Bangunan. Ketentuan dalam Undang-Undang No. 40 Tahun 1996 tentang Hak Guna Usaha, Hak Guna Bangunan, dan Hak Pakai Atas Tanah, yang menetapkan bahwa hak atas tanah hapus karena pencabutan hak atas tanah, yaitu Pasal 17 ayat (1) huruf (d) untuk Hak Guna Usaha, Pasal 35 ayat (1) huruf (d) untuk Hak Guna Bangunan, dan Pasal 55 ayat (1) huruf (d) untuk Hak Pakai.

Pasal 1 Undang-Undang No. 20 Tahun 1961 menetapkan bahwa untuk kepentingan umum, termasuk kepentingan bangsa dan negara serta kepentingan bersama dari rakyat, demikian pula kepentingan pembangunan, maka Presiden dalam keadaan yang memaksa, setelah mendengar Menteri Agraria, Menteri Kehakiman, dan Menteri yang bersangkutan dapat mencabut hak-hak atas tanah

3 Urip Santoso, Hukum Pengadaan Tanah Untuk Kepentingan Umum, Airlangga University Press, Surabaya, 2013, h. 11. dan benda-benda yang ada di atasnya. Ketentuan pencabutan hak atas tanah dalam Pasal 1 UndangUndang No. 20 Tahun 1961, adalah: Hanya Presiden yang berwenang melakukan pencabutan hak atas tanah; Pencabutan hak atas tanah dilakukan untuk kepentingan umum, termasuk kepentingan bangsa dan negara serta kepentingan bersama dari rakyat, demikian pula kepentingan pembangunan; Pencabutan hak atas tanah dilakukan dalam keadaan yang memaksa; Sebelum melakukan pencabutan hak atas tanah, Presiden mendengar Menteri Agraria, Menteri Kehakiman, dan Menteri yang bersangkutan.

Pencabutan hak atas tanah diatur dalam UndangUndang No. 20 Tahun 1961, akan tetapi UndangUndang No. 20 Tahun 1961 tidak memberikan pengertian pencabutan hak atas tanah. Menurut Effendi Perangin, yang dimaksud pencabutan hak atas tanah adalah pengambilan tanah kepunyaan sesuatu pihak oleh negara secara paksa, yang mengakibatkan hak atas tanah menjadi hapus, tanpa yang bersangkutan melakukan pelanggaran atau lalai dalam memenuhi sesuatu kewajiban hukum. ${ }^{4}$ Aminuddin Salle menyatakan bahwa Pencabutan hak atas tanah adalah kewenangan yang diberikan oleh Undang-Undang kepada Pemerintah, dalam hal ini Presiden. Bentuk kewenangan yang diberikan oleh Undang-Undang adalah untuk melakukan tindakan secara paksa mengambil dan menguasai tanah seseorang untuk kepentingan umum. ${ }^{5}$

Pencabutan hak atas tanah adalah pengambilan tanah yang dimiliki atau dikuasai oleh perseorangan atau badan hukum secara paksa oleh negara untuk kepentingan umum tanpa yang bersangkutan melakukan pelanggaran atau lalai dalam memenuhi sesuatu kewajiban hukum, dengan pemberian ganti kerugian yang layak yang mengakibatkan hak atas tanah menjadi hapus dan tanahnya kembali menjadi tanah negara atau tanah yang dikuasai langsung oleh negara.

Terdapat 5 (lima) syarat pencabutan hak atas tanah menurut Undang-Undang No. 20 Tahun 1961, yaitu: a. Dilakukan untuk kepentingan umum,

\footnotetext{
${ }^{4}$ Abdurrahman, Masalah-masalah Pencabutan Hak Atas Tanah dan Pengadaan Tanah Bagi Pelaksanaan Pembangunan Untuk Kepentingan Umum, Citra Aditya Bakti, Bandung, 1996, h. 38 .

5 Aminuddin Salle, Hukum Pengadaan Tanah Untuk Kepentingan Umum, Kreasi Total Media, Yogyakarta, 2007, h. 101.
} 
termasuk kepentingan bangsa dan negara serta kepentingan bersama dari rakyat, demikian pula kepentingan pembangunan; b. Pemberian ganti kerugian yang layak kepada pemegang hak atas tanah yang terkena pencabutan hak atas tanah; c. Dilakukan menurut cara yang diatur dengan undang-undang; $d$. Pemindahan hak atas tanah tidak dapat dilakukan; e. Tidak mungkin diperoleh tanah di tempat lain untuk keperluan tersebut.

Untuk menampung permohonan pencabutan hak atas tanah dan benda-benda yang ada di atasnya, Pemerintah telah mengatur pedoman dengan memperhatikan berbagai segi, baik mengenai tafsiran "untuk kepentingan umum" maupun proses pelaksanaannya dengan mengingat asas perlindungan hukum dan kepastian hukum terhadap hak atas tanah dan benda-benda yang ada di atasnya. Pencabutan hak atas tanah dan benda-benda yang ada di atasnya hanya dapat dilakukan dengan Undang-Undang apabila benar-benar untuk kepentingan umum, dalam keadaan terpaksa dan sangat mendesak demi untuk kepentingan umum/negara/bangsa dengan pembayaran ganti rugi dan dilakukan dengan hatihati serta dengan cara-cara yang adil dan bijaksana, segala sesuatu sesuai dengan ketentuan peraturan perundang-undangan yang berlaku. ${ }^{6}$

Perolehan tanah untuk kepentingan umum didahului oleh musyawarah antara pemilik atau pemegang hak atas tanah dengan pihak yang memerlukan tanah untuk menetapkan bentuk dan besarnya ganti kerugian. Oleh karena dalam musyawarah tidak mencapai kesepakatan sedangkan tanah diperlukan untuk kepentingan umum dan sifatnya mendesak, maka ditempuhlah upaya pencabutan hak atas tanah. Eman menyatakan bahwa pelaksanaan pencabutan hak atas tanah bersifat ultimum remidium artinya pencabutan hanya akan dilakukan jika cara-cara lain tidak dapat ditempuh atau diupayakan. ${ }^{7}$

Pencabutan hak atas tanah untuk kepentingan umum merupakan cara terakhir untuk memperoleh tanah yang diperlukan guna untuk kepentingan

\footnotetext{
${ }^{6}$ R. Soeprapto, Undang-Undang Pokok Agraria Dalam Praktek, Universitas Indonesia Press, Jakarta, 1986, h. 276.

${ }^{7}$ Eman, “Aspek Kepentingan Umum Dalam Pencabutan Hak Atas Tanah Setelah Berlakunya Keputusan Presiden Republik Indonesia No. 55 Tahun 1993”, Majalah Yuridika, No. 1 Tahun XI, Fakultas Hukum Universitas Airlangga, JanuariFebruari 1996, h. 68.
}

umum, setelah musyawarah dengan pemegang hak atas tanah tidak mencapai kesepakatan, sedangkan keperluan akan tanah sifatnya sangat mendesak.

Undang-Undang No. 20 Tahun 1961 menetapkan bahwa pihak yang memerlukan tanah dalam pencabutan hak atas tanah tidak hanya instansi Pemerintah (Pemerintah atau Pemerintah Daerah) untuk keperluan usaha-usaha negara, akan tetapi usaha swasta (perusahaan swasta) juga dapat memperoleh tanah melalui pencabutan hak atas tanah, sepanjang kegiatannya benar-benar untuk kepentingan umum.

Pencabutan hak atas tanah dilakukan dalam rangka perolehan tanah untuk kepentingan umum. Dalam Lampiran Pasal 1 ayat (1) Instruksi Presiden No. 9 Tahun 1973 ditetapkan bahwa suatu kegiatan dalam rangka pelaksanaan pembangunan mempunyai sifat kepentingan umum, apabila kegiatan tersebut menyangkut: kepentingan bangsa dan negara, masyarakat luas, rakyat banyak/masyarakat, dan/ atau kepentingan pembangunan.

Dalam Lampiran Pasal 1 ayat (2) Instruksi Presiden No. 9 Tahun 1973 ditetapkan bahwa bentukbentuk kegiatan pembangunan yang mempunyai sifat kepentingan umum, meliputi bidang-bidang: pertahanan; pekerjaan umum; perlengkapan umum; jasa umum; keagamaan; ilmu pengetahuan dan sosial budaya; kesehatan; olahraga; keselamatan umum terhadap bencana alam; kesejahteraan sosial; makam/ kuburan; pariwisata dan rekreasi; dan, usaha-usaha ekonomi yang bermanfaat bagi kesejahteraan umum.

Yang dapat menjadi subjek atau pemohon untuk mengajukan permohonan pencabutan hak atas tanah, adalah instansi-instansi Pemerintah/badan-badan Pemerintah; serta usaha-usaha swasta.

Pencabutan hak atas tanah dapat dilakukan kalau ada permohonan dari pihak yang berkepentingan, instansi-instansi Pemerintah/badan-badan Pemerintah atau usaha-usaha swasta. Pencabutan hak atas tanah diajukan kepada Presiden dengan perantaraan Menteri Agraria melalui Kepala Inspeksi Agraria yang bersangkutan (sekarang Kepala Kantor Wilayah Badan Pertanahan Nasional Provinsi).

Dalam pencabutan hak atas tanah ada pemberian ganti kerugian yang layak kepada pemegang hak atas tanah yang terkena pencabutan hak atas tanah. Ganti kerugian atas tanah dan/atau benda-benda yang haknya akan dicabut ditaksir oleh Panitia Penaksir. 
Dalam menetapkan besar ganti kerugian atas tanah/ bangunan/tanaman yang berada di atasnya harus menaksir secara objektif dengan tidak merugikan kedua belah pihak (pemohon pencabutan hak atas tanah dan pihak yang memerlukan tanah) dan dengan menggunakan norma-norma serta memperhatikan harga-harga penjualan tanah/bangunan/tanaman di sekitarnya yang terjadi dalam tahun yang sedang berjalan.

Pasal 5 Undang-Undang No. 20 Tahun 1961 menetapkan bahwa pencabutan hak atas tanah ditetapkan dengan Keputusan Presiden Republik Indonesia. Dalam Keputusan Presiden Republik Indonesia ditetapkan besarnya ganti kerugian atas tanah/bangunan/tanaman yang berada di atasnya. Presiden Republik menerbitkan Keputusan tentang pencabutan hak atas tanah setelah mendengar Menteri Agraria, Menteri Kehakiman, dan Menteri yang bersangkutan yang tugasnya meliputi kegiatan yang meminta dilakukannya pencabutan hak atas tanah. Keputusan Presiden Republik Indonesia tentang pencabutan hak atas tanah diumumkan dalam Berita Negara Republik Indonesia atas biaya dari pemohon pencabutan hak atas tanah dan turunannya disampaikan kepada yang berhak atas tanah dan/atau benda-benda yang haknya dicabut.

Pejabat yang berwenang melakukan pencabutan hak atas tanah menurut Undang-Undang No. 20 Tahun 1961 adalah Presiden Republik Indonesia. Kewenangan untuk melakukan pencabutan hak atas tanah merupakan kewenangan yang sifatnya atribusi bagi Presiden Republik Indonesia, tidak dilimpahkan kepada Menteri, Gubernur, Bupati/Walikota, atau pejabat lain.

Pasal 8 Undang-Undang No. 20 Tahun 1961 menetapkan bahwa jika yang berhak atas tanah dan/ atau benda-benda yang haknya dicabut tidak bersedia menerima ganti kerugian sebagaimana ditetapkan dalam Keputusan Presiden Republik Indonesia karena dianggap jumlahnya tidak layak, maka ia dapat meminta banding kepada Pengadilan Tinggi, yang daerah kerjanya meliputi letak tanah yang terkena pencabutan hak atas tanah agar Pengadilan Tinggi yang menetapkan jumlah ganti kerugian yang layak. Putusan Pengadilan Tinggi merupakan putusan yang pertama dan terakhir dalam penyelesaian sengketa dalam pencabutan hak atas tanah. Penyelesaian sengketa dalam pencabutan hak atas tanah di
Pengadilan Tinggi tidak menunda pelaksanaan pencabutan hak atas tanah dan penguasaannya.

Pasal 9 Undang-Undang No. 20 Tahun 1961 menetapkan akibat hukum pencabutan hak atas tanah yang ditetapkan dalam Keputusan Presiden Republik Indonesia dan setelah dilakukannya pembayaran ganti kerugian kepada yang berhak, yaitu hak atas tanah menjadi hapus dan tanahnya kembali menjadi tanah yang dikuasai langsung oleh negara, untuk segera diberikan kepada pemohon pencabutan hak atas tanah dengan suatu hak atas tanah yang sesuai.

Pasal 11 Undang-Undang No. 20 Tahun 1961 menetapkan bahwa jika hak atas tanah telah dicabut untuk kepentingan umum, tetapi kemudian ternyata bahwa tanah dan/atau benda-benda yang bersangkutan tidak dipergunakan sesuai dengan rencana peruntukannya, yang mengharuskan dilakukan pencabutan hak atas tanah, maka bekas pemilik tanah diberi prioritas pertama untuk mendapatkan kembali tanah dan/atau benda-benda tersebut.

Pencabutan hak atas tanah untuk kepentingan umum dengan pemberian ganti kerugian yang layak kepada pemegang hak atas tanah yang ditetapkan dengan Keputusan Presiden Republik Indonesia merupakan faktor penyebab hapusnya hak atas tanah dan berakibat hak atas tanah kembali menjadi tanah negara atau yang dikuasai langsung oleh negara.

\section{Pengadaan Tanah Untuk Kepentingan Umum}

Semula, pengadaan tanah untuk kepentingan umum diatur oleh Keputusan Presiden Republik Indonesia No. 55 Tahun 1993 tentang Pengadaan Tanah Bagi Pelaksanaan Pembangunan Untuk Kepentingan Umum. Keputusan Presiden Republik Indonesia No. 55 Tahun 1993 dilaksanakan oleh Peraturan Menteri Negara Agraria/Kepala Badan Pertanahan Nasional No. 1 Tahun 1994 tentang Ketentuan Pelaksanaan Keputusan Presiden Republik Indonesia Nomor 55 Tahun 1993 tentang Pengadaan Tanah Bagi Pelaksanaan Pembangunan Untuk Kepentingan Umum.

Keputusan Presiden Republik Indonesia No. 55 Tahun 1993 dinyatakan tidak berlaku oleh Peraturan Presiden Republik Indonesia No. 36 Tahun 2005 tentang Pengadaan Tanah Bagi Pelaksanaan Pembangunan Untuk Kepentingan Umum. Peraturan Presiden Republik Indonesia No. 36 Tahun 2005 
diubah oleh Peraturan Presiden Republik Indonesia No. 65 Tahun 2006 tentang Perubahan Atas Peraturan Presiden Republik Indonesia Nomor 36 Tahun 2005 tentang Pengadaan Tanah Bagi Pelaksanaan Pembangunan Untuk Kepentingan Umum. Peraturan Presiden Republik Indonesia No. 36 Tahun 2005 dilaksanakan oleh Peraturan Kepala Badan Pertanahan Nasional Republik Indonesia No. 3 Tahun 2007 tentang Ketentuan Pelaksanaan Peraturan Presiden Republik Indonesia No. 36 Tahun 2005 sebagaimana diubah oleh Peraturan Presiden Republik Indonesia No. 65 Tahun 2006 tentang Perubahan Atas Peraturan Presiden Republik Indonesia Nomor 36 Tahun 2005 tentang Pengadaan Tanah Bagi Pelaksanaan Pembangunan Untuk Kepentingan Umum. Peraturan Kepala Badan Pertanahan Nasional Republik Indonesia No. 3 Tahun 2007 menyatakan tidak berlaku Peraturan Menteri Negara Agraria/Kepala Badan Pertanahan Nasional No. 1 Tahun 1994.

Pada tahun 2012 diundangkan UndangUndang No. 2 Tahun 2012 tentang Pengadaan Tanah Bagi Pelaksanaan Pembangunan Untuk Kepentingan Umum. Undang-Undang No. 2 Tahun 2012 dilaksanakan oleh Peraturan Presiden Republik Indonesia Nomor 71 Tahun 2012 tentang Penyelenggaraan Pengadaan Tanah Bagi Pelaksanaan Pembangunan Untuk Kepentingan Umum, dan Peraturan Kepala Badan Pertanahan Nasional Republik Indonesia No. 5 Tahun 2012 tentang Petunjuk Teknis Pengadaan Untuk Kepentingan Umum. Peraturan Presiden Republik Indonesia Nomor 71 Tahun 2012 menyatakan tidak berlaku Peraturan Presiden Republik Indonesia Nomor 36 Tahun 2005.

Sudah tepat bahwa pengaturan pengadaan tanah untuk kepentingan umum tidak dalam bentuk Peraturan Presiden, melainkan dalam bentuk undangundang yaitu Undang-Undang No. 2 Tahun 2012 sebab di dalamnya mengatur hak dan kewajiban warga negara Indonesia. Dalam Undang-Undang No. 2 Tahun 2012 diatur hak dari pihak yang berhak atas objek pengadaan tanah untuk mendapatkan ganti kerugian yang layak dan adil, dan pihak yang berhak atas objek pengadaan tanah berkewajiban mematuhi ketentuan dalam Undang-Undang No. 2 Tahun 2012. ${ }^{8}$

\footnotetext{
${ }^{8}$ Urip Santoso, Op.Cit., h. 37.
}

Ida Nurlinda menyatakan bahwa Undang-Undang No. 2 Tahun 2012 dilaksanakan oleh Peraturan Presiden RI Nomor 71 Tahun 2012, baik dari segi bentuk hukumnya yang berupa undang-undang maupun materi muatannya yang memuat aturan mengenai penilaian pertanahan serta adanya proses konsultasi publik sebagai suatu proses komunikasi yang dialogis, memang tampak lebih baik dari aturan-aturan serupa sebelumnya. Namun, jika dikaji lebih dalam, undang-undang tersebut berpotensi menimbulkan konflik dan/atau sengketa pertanahan. ${ }^{9}$

Peraturan Presiden Republik Indonesia Nomor 71 Tahun 2012 diubah sebanyak 4 (empat) kali, yaitu: Peraturan Presiden Republik Indonesia Nomor 40 Tahun 2014, Peraturan Presiden Republik Indonesia Nomor 99 Tahun 2014, Peraturan Presiden Republik Indonesia Nomor 30 Tahun 2015, dan Peraturan Presiden Republik Indonesia Nomor 148 Tahun 2015.

Pengertian pengadaan tanah disebutkan dalam Pasal 1 angka 2 Undang-Undang No. 2 Tahun 2012, yaitu kegiatan menyediakan tanah dengan cara memberikan ganti kerugian yang layak dan adil kepada pihak yang berhak. Pengertian pengadaan tanah untuk kepentingan umum adalah kegiatan menyediakan tanah untuk kepentingan umum oleh Pelaksana Pengadaan Tanah sesuai dan berdasar kepada Rencana Tata Ruang Wilayah, Rencana Pembangunan Nasional/Daerah, Rencana Strategis, atau rencana kerja instansi yang memerlukan tanah dengan cara cara memberikan ganti kerugian yang layak dan adil kepada pihak yang berhak.

Pihak yang memerlukan tanah dalam pengadaan tanah untuk kepentingan umum adalah instansi. Pengertian instansi semula disebutkan dalam Pasal 1 angka 1 Undang-Undang No. 2 Tahun 2012 juncto Pasal 1 angka 1 Peraturan Presiden Republik Indonesia Nomor 71 Tahun 2012, yaitu lembaga negara, kementerian dan lembaga Pemerintah non kementerian, pemerintah provinsi, pemerintah kabupaten/kota, dan Badan Hukum Milik Negara/ Badan Usaha Milik Negara yang mendapat penugasan khusus Pemerintah. Pengertian instansi yang disebutkan dalam Pasal 1 angka 1 Undang-Undang

\footnotetext{
${ }^{9}$ Ida Nurlinda, "Penyelesaian Sengketa dan/atau Konflik Dalam Pengadaan Tanah Untuk Kepentingan Umum”, Makalah, Seminar Nasional Pengadaan Tanah Untuk Kepentingan Umum Pasca Berlakunya Undang-Undang No. 2 Tahun 2012, Program Pascasarjana Universitas Airlangga, Surabaya, 27 September 2012, h. 8.
} 
No. 2 Tahun 2012 juncto Pasal 1 angka 1 Peraturan Presiden Republik Indonesia Nomor 71 Tahun 2012 diubah oleh Pasal 1 angka 1 Peraturan Presiden Republik Indonesia Nomor 148 Tahun 2015, yaitu instansi adalah lembaga negara, kementerian dan lembaga Pemerintah non kementerian, pemerintah provinsi, pemerintah kabupaten/kota, dan Badan Hukum Milik Negara/Badan Usaha Milik Negara yang mendapat penugasan khusus Pemerintah atau badan usaha yang mendapatkan kuasa berdasarkan perjanjian dari lembaga negara, kementerian dan lembaga pemerintah non kementerian, pemerintah provinsi, pemerintah kabupaten/kota, dan Badan Hukum Milik Negara/Badan Usaha Milik Negara yang mendapat penugasan khusus Pemerintah dalam rangka penyediaan infrastruktur untuk kepentingan umum.

Undang-Undang No. 2 Tahun 2012 mengatur pengadaan tanah yang diorientasikan untuk kepentingan umum. Pengertian kepentingan umum dalam pengadaan tanah untuk kepentingan umum disebutkan dalam Pasal 1 angka 6 UndangUndang No. 2 Tahun 2012 juncto Pasal 1 angka 6 Peraturan Presiden Republik Indonesia Nomor 148 Tahun 2015, yaitu kepentingan bangsa, negara, dan masyarakat yang harus diwujudkan oleh Pemerintah dan dipergunakan untuk sebesar-besar kemakmuran rakyat. Bidang kegiatan pembangunan yang termasuk kepentingan umum ada 18 (delapan belas) macam sebagaimana disebutkan dalam Pasal 10 UndangUndang No. 2 Tahun 2012.

Berdasarkan ketentuan Pasal 1 angka 6 UndangUndang No. 2 Tahun 2012 juncto Pasal 1 angka 6 Peraturan Presiden Republik Indonesia Nomor 148 Tahun 201, muatan dalam kepentingan umum, yaitu: pertama, Ruang lingkup kepentingan umum adalah kepentingan bangsa, negara, dan masyarakat yang harus diwujudkan oleh Pemerintah, dan kedua, Tujuan kepentingan umum adalah dipergunakan untuk sebesar-besar kemakmuran rakyat.

Penggunaan tanah untuk kepentingan umum merupakan implementasi dari asas hak atas tanah mempunyai fungsi sosial sebagaimana ditetapkan dalam Pasal 6 Undang-Undang No. 5 Tahun 1960. Dalam menggunakan tanah harus mengedepankan atau mengutamakan kepentingan umum, termasuk kepentingan bangsa dan negara serta kepentingan bersama dari rakyat daripada kepentingan pribadinya.
Apabila kepentingan umum menghendaki diambilnya hak atas tanah, maka pemegang hak atas tanah atau melepaskan hak atas tanah dengan pemberian ganti kerugian yang layak melalui mekanisme pencabutan hak atas tanah. ${ }^{10}$

Maria SW Sumardjono menyatakan bahwa pada umumnya terdapat dua cara untuk mengungkapkan tentang doktrin kepentingan umum, yaitu: pertama, Pedoman umum, yang secara umum menyebutkan bahwa pengadaan tanah berdasarkan alasan kepentingan umum. Istilah-istilah yang sering digunakan secara bergantian untuk mengungkapkan tentang pengertian umum tersebut misalnya public atau social, general, common, collective, sedangkan untuk istilah kepentingan atau purpose sering diganti dengan istilah need, necessity, interest, function, utility, atau uses; kedua, Penyebutan kepentingan umum dalam suatu daftar kegiatan yang secara jelas mengidentifikasi tujuannya: sekolah, jalan, bangunan-bangunan Pemerintah, dan sebagainya, yang oleh peraturan perundang-undangan dipandang bermanfaat untuk umum. Segala kegiatan di luar yang tercantum dalam daftar tersebut tidak dapat dijadikan alasan untuk pengadaan tanah. ${ }^{11}$

Pengadaan tanah untuk kepentingan umum diselenggarakan sesuai dengan Rencana Tata Ruang Wilayah, Rencana Pembangunan Nasional/Daerah, Rencana Strategis, dan Rencana Kerja setiap instansi yang memerlukan tanah. Dalam hal pengadaan tanah dilakukan untuk infrastruktur minyak, gas, dan panas bumi, pengadaannya diselenggarakan berdasarkan Rencana Strategis dan Rencana Kerja setiap instansi yang memerlukan tanah.

Pengadaan tanah untuk kepentingan umum dilaksanakan oleh Pelaksana Pengadaan Tanah. Pelaksana Pengadaan Tanah adalah Badan Pertanahan Nasional Republik Indonesia. Pelaksanaan pengadaan tanah untuk kepentingan umum dilakukan oleh Kepala Kantor Wilayah Badan Pertanahan Nasional Provinsi. Kepala Kantor Wilayah Badan Pertanahan Nasional Provinsi dapat menugaskan Kepala Kantor Pertanahan Kabupaten/Kota.

Objek pengadaan tanah untuk kepentingan umum adalah tanah, ruang atas tanah dan bawah tanah,

${ }^{10}$ Urip Santoso, Hukum Agraria Kajian Komprehensif, Kencana Prenada Media, Jakarta, 2014, h. 58-59.

${ }^{11}$ Maria S.W. Sumardjono, Tanah Dalam Perspektif Hak Ekonomi Sosial dan Budaya, Kompas, Jakarta, 2008, h. 241. 
bangunan, tanaman, benda yang berkaitan dengan tanah, atau lainnya yang dapat dinilai.

Dalam pengadaan tanah untuk kepentingan umum diberikan ganti kerugian kepada pihak yang berhak. Pengertian ganti kerugian disebutkan dalam Pasal 1 angka 10 Undang-Undang No. 2 Tahun 2012 juncto Pasal 1 angka 10 Peraturan Presiden Republik Indonesia Nomor 148 Tahun 2015, yaitu penggantian yang layak dan adil kepada pihak yang berhak dalam proses pengadaan. Benda-benda yang diberikan ganti kerugian adalah: tanah, ruang atas tanah dan bawah tanah, bangunan, tanaman, benda yang berkaitan dengan tanah.

Pemberian ganti kerugian dapat diberikan dalam dalam pengadaan tanah untuk kepentingan umum berbentuk: uang, tanah pengganti, permukiman kembali, kepemilikan saham, atau bentuk lain yang disetujui oleh kedua belah pihak.

Pihak yang berhak sebagai penerima ganti kerugian dalam pengadaan tanah untuk kepentingan umum, adalah: pemegang hak atas tanah; pemegang Hak Pengelolaan; nadzir untuk tanah wakaf; pemilik tanah bekas milik adat; masyarakat hukum; pihak yang menguasai tanah negara dengan itikad baik; pemegang dasar penguasaan atas tanah; dan pemilik bangunan, tanaman atau benda lain yang berkaitan dengan tanah.

Penetapan besarnya ganti kerugian dalam pengadaan tanah untuk kepentingan umum dilakukan oleh Penilai Pertanahan. Pengertian Penilai Pertanahan disebutkan dalam Pasal 1 angka 11 Undang-Undang No. 2 Tahun 2012 juncto Pasal 1 angka 11 Peraturan Presiden Republik Indonesia Nomor 148 Tahun 2015, adalah orang perorangan yang melakukan penilaian secara independen dan profesional yang telah mendapat izin praktik penilaian dari Menteri Keuangan dan telah mendapat lisensi dari Lembaga Pertanahan untuk menghitung nilai/ harga objek pengadaan tanah. Penilai Pertanahan ditetapkan oleh Menteri Agraria dan Tata Ruang/ Kepala Badan Pertanahan Nasional Republik Indonesia sebagai Lembaga Pertanahan sesuai dengan ketentuan peraturan perundang-undangan yang berkaitan dengan pengadaan barang dan jasa.

Cara perolehan tanah dalam pengadaan tanah untuk kepentingan umum ditempuh melalui pelepasan hak oleh pihak yang berhak sebagaimana ditetapkan dalam Pasal 5 Undang-Undang No. 2 Tahun
201, yaitu pihak yang berhak wajib melepaskan tanahnya pada saat pelaksanaan pengadaan tanah untuk kepentingan umum setelah pemberian ganti kerugian atau berdasarkan putusan pengadilan yang telah memperoleh kekuatan hukum tetap.

Pelaksanaan perolehan tanah dalam pengadaan tanah untuk kepentingan umum didahului oleh musyawarah antara Pelaksana Pengadaan Tanah dengan pihak yang berhak untuk menetapkan bentuk dan besarnya ganti kerugian. Hasil musyawarah antara Pelaksana Pengadaan Tanah dengan pihak yang berhak dapat berupa mencapai kesepakatan atau tidak mencapai kesepakatan.

Pelaksana Pengadaan Tanah melaksanakan musyawarah dengan pihak yang berhak. Pelaksanaan musyawarah dilaksanakan dengan mengikutsertakan instansi yang memerlukan tanah. Musyawarah dilakukan secara langsung untuk menetapkan bentuk dan besarnya ganti kerugian berdasarkan hasil penilaian ganti kerugian oleh Penilai Pertanahan. Dalam musyawarah antara Pelaksana Pengadaan Tanah dan pihak yang berhak, yang diikuti serta oleh instansi yang memerlukan tanah, Pelaksana Pengadaan Tanah menyampaikan besarnya ganti kerugian hasil penilaian ganti kerugian oleh Penilai Pertanahan.

Dalam hal pihak yang berhak telah diundang secara patut tidak hadir dan tidak memberikan kuasa, pihak yang berhak dianggap menerima bentuk dan besarnya ganti kerugian yang ditetapkan oleh Pelaksana Pengadaan Tanah.

Dalam musyawarah dapat menghasilkan kesepakatan antara Pelaksana Pengadaan Tanah dengan pihak yang berhak mengenai bentuk dan besarnya ganti kerugian. Hasil kesepakatan dalam musyawarah menjadi dasar pemberian ganti kerugian kepada pihak yang berhak yang dituangkan dalam berita acara kesepakatan.

Sebagai tindak lanjut kesepakatan dalam musyawarah antara Pelaksana Pengadaan Tanah dan pihak yang berhak mengenai bentuk dan besarnya ganti kerugian dilaksanakan pemberian ganti kerugian. Pemberian ganti kerugian atas objek pengadaan tanah dilakukan langsung kepada pihak yang berhak oleh instansi yang memerlukan tanah berdasarkan hasil penilaian yang ditetapkan dalam musyawarah. 
Pada saat pemberian ganti kerugian, pihak yang berhak menerima ganti kerugian wajib: Melakukan pelepasan hak; dan Menyerahkan bukti penguasaan atau kepemilikan objek pengadaan tanah kepada instansi yang memerlukan tanah melalui Lembaga Pertanahan (Badan Pertanahan Nasional Republik Indonesia).

Bukti penguasaan atau kepemilikan objek pengadaan tanah merupakan satu-satunya alat bukti yang sah menurut hukum dan tidak dapat diganggu gugat di kemudian hari. Pihak yang berhak menerima ganti kerugian bertanggung jawab atas kebenaran dan keabsahan bukti penguasaan atau kepemilikan yang diserahkan. Tuntutan pihak lain objek pengadaan tanah yang telah diserahkan kepada instansi yang memerlukan tanah menjadi tanggung jawab pihak yang berhak menerima ganti kerugian.

Pasal 43 Undang-Undang No. 2 Tahun 2012 menetapkan bahwa pada saat pelaksanaan pemberian ganti kerugian dan pelepasan hak telah dilaksanakan, kepemilikan atau hak atas tanah dari pihak yang berhak menjadi hapus dan alat bukti haknya dinyatakan tidak berlaku dan tanahnya menjadi tanah yang dikuasai langsung oleh negara. Pada saat pelaksanaan pemberian ganti kerugian dan setelah berita acara atau surat pernyataan pelepasan hak atas objek pengadaan tanah dibuat oleh pihak yang berhak, maka alat bukti haknya, misalnya sertipikat atau Petuk Pajak Bumi (Kutipan Letter C) dinyatakan tidak berlaku. Hapusnya hak atas tanah sebagai objek pengadaan tanah didaftar oleh Kepala Kantor Pertanahan Kabupaten/Kota setempat.

Pengertian pelepasan hak disebutkan dalam Pasal 1 angka 9 Undang-Undang No. 2 Tahun 2012 juncto Pasal 1 angka 9 Peraturan Presiden Republik Indonesia Nomor 148 Tahun 2015, yaitu kegiatan pemutusan hubungan hukum dari pihak yang berhak kepada negara melalui kementerian. Pelepasan hak atas tanah adalah kegiatan pemutusan hubungan hukum oleh pemegang hak atas tanah dengan hak atas tanah yang dikuasainya dengan atau tanpa pemberian ganti kerugian yang layak dan adil kepada pemegang hak atas tanah oleh pihak yang memerlukan tanah, yang berakibat hak atas tanah menjadi hapus dan hak atas tanah kembali menjadi tanah negara atau tanah yang dikuasai langsung oleh negara.

Pelepasan hak atas tanah dilakukan oleh pihak yang berhak menerima ganti kerugian kepada negara dihadapan Kepala Kantor Pertanahan Kabupaten/ Kota setempat. Pelepasan hak atas tanah dibuat dengan berita acara pelepasan atau surat pernyataan pelepasan hak objek pengadaan tanah.

Ari S. Hutagalung menyatakan bahwa acara pelepasan hak ditempuh jika pihak yang bermaksud memperoleh dan menguasai tanah yang berstatus Hak Milik atau eks Hak Milik Adat, namun tidak memenuhi syarat sebagai subjek pemegang hak atas tanah tersebut melalui pemindahan hak/peralihan hak secara langsung. ${ }^{12}$ Kalau tanah yang diperlukan oleh instansi yang memerlukan tanah berstatus Hak Milik, sedangkan instansi yang memerlukan tanah bukan subjek Hak Milik, maka cara perolehan tanah melalui pemindahan hak atas tanah dalam bentuk jual beli tidak dapat dilakukan disebabkan secara materiil, instansi yang memerlukan tanah tidak memenuhi syarat sebagai pembeli tanah. Karena cara perolehan tanah melalui pemindahan hak atas tanah dalam bentuk jual beli tidak dapat dilakukan, maka cara perolehan tanah yang dapat ditempuh oleh instansi yang memerlukan tanah dalam pengadaan tanah untuk kepentingan umum adalah melalui pelepasan hak atas tanah oleh pemegang hak atas tanah dengan pemberian ganti kerugian yang layak.

Boedi Harsono menyatakan bahwa dengan pelepasan hak atas tanah tidak berarti bahwa hak atas tanah berpindah dari pemegang hak atas tanah kepada pihak lain yang memberikan ganti kerugian, melainkan hak atas tanah tersebut hapus dan kembali menjadi tanah negara atau tanah yang dikuasai langsung oleh negara. Pelepasan hak atas tanah merupakan salah satu faktor penyebab hapusnya hak atas tanah dan bukan pemindahan hak atas tanah. ${ }^{13}$ Pelepasan hak atas tanah merupakan hapusnya hak atas tanah dan bukan pemindahan hak atas tanah. Dengan pelepasan hak atas tanah berakibat hak atas tanah berakibat hak atas tanah menjadi hapus dan hak atas tanah kembali menjadi tanah negara atau tanah yang dikuasai langsung oleh negara. Dengan pelepasan hak atas tanah tidak berakibat hak atas tanah berpindah kepada instansi yang memerlukan

\footnotetext{
${ }^{12}$ Arie S. Hutagalung, Serba Aneka Masalah Tanah Dalam Kegiatan Ekonomi, Badan Penerbit Fakultas Hukum Universitas Indonesia, Jakarta, 2002, h. 179.

${ }^{13}$ Boedi Harsono, "Aspek Yuridis Penyediaan Tanah", Majalah Hukum dan Pembangunan, Nomor 2 Tahun XX, Fakultas Hukum Universitas Indonesia, Jakarta, April 1990, h. 168.
} 
tanah yang memberikan ganti kerugian kepada pemegang hak atas tanah sebagai pihak yang berhak.

Akibat hukum dari pelepasan hak atas tanah adalah hak atas tanah menjadi hapus dan hak atas tanah kembali menjadi tanah negara atau tanah yang dikuasai langsung oleh negara. Pengertian tanah negara atau tanah yang dikuasai langsung oleh negara disebutkan dalam Pasal 1 angka 3 Peraturan Pemerintah No. 24 Tahun 1997 tentang Pendaftaran Tanah, tanah negara atau tanah yang dikuasai langsung oleh negara adalah tanah yang tidak dipunyai dengan sesuatu hak atas tanah. Tanah negara atau tanah yang dikuasai langsung oleh negara adalah tanah yang di atasnya belum terdapat atau belum dibebani dengan hak atas tanah tertentu yang dimiliki atau dikuasai oleh perseorangan atau badan hukum.

Dalam hal musyawarah antara antara Pelaksana Pengadaan Tanah dengan pihak yang berhak untuk menetapkan bentuk dan besarnya ganti kerugian tidak mencapai kesepakatan, yaitu pihak yang berhak tidak menyetujui besarnya ganti kerugian yang ditetapkan oleh Pelaksana Pengadaan Tanah, maka Pasal 38 Undang-Undang No. 2 Tahun 2012 juncto Pasal 73 Peraturan Presiden Republik Indonesia Nomor 71 Tahun 2012 menetapkan bahwa pihak yang berhak dapat mengajukan keberatan kepada pengadilan negeri setempat dalam waktu paling lama 14 (empat belas) hari kerja setelah musyawarah penetapan ganti kerugian. Pengadilan negeri memutus bentuk dan/ atau besarnya ganti kerugian dalam waktu paling lama 30 (tiga puluh) hari kerja sejak diterimanya pengajuan keberatan. Pihak yang keberatan terhadap putusan pengadilan negeri dalam waktu paling lama 14 (empat belas) hari kerja dapat mengajukan kasasi kepada Mahkamah Agung Republik Indonesia. Mahkamah Agung Republik Indonesia memberi putusan dalam waktu paling lama 30 (tiga puluh) hari kerja sejak permohonan kasasi diterima. Putusan Pengadilan Negeri/Mahkamah Agung Republik Indonesia yang telah memperoleh kekuatan hukum tetap menjadi dasar pembayaran ganti kerugian kepada pihak yang mengajukan keberatan.

Pasal 39 Undang-Undang No. 2 Tahun 2012 menetapkan bahwa dalam hal pihak yang berhak menolak bentuk dan/atau besarnya ganti kerugian yang ditetapkan oleh Pelaksana Pengadaan Tanah, tetapi tidak mengajukan keberatan kepada pengadilan negeri setempat, karena hukum pihak yang berhak dianggap menerima bentuk dan besarnya ganti kerugian yang ditetapkan oleh Pelaksana Pengadaan Tanah.

Pasal 42 Undang-Undang No. 2 Tahun 2012 menetapkan bahwa dalam hal pihak yang berhak menolak bentuk dan/atau besarnya ganti kerugian berdasarkan musyawarah antara Pelaksana Pengadaan Tanah dan pihak yang berhak atau putusan pengadilan negeri/Mahkamah Agung Republik Indonesia yang berkekuatan hukum tetap, ganti kerugian dititipkan di pengadilan negeri setempat oleh instansi yang memerlukan. Penitipan ganti kerugian dalam pengadaan tanah untuk kepentingan umum juga dilakukan terhadap: Pihak yang berhak menerima ganti kerugian tidak diketahui keberadaannya; Objek pengadaan tanah yang akan diberikan ganti kerugian sedang menjadi objek perkara di pengadilan; Masih dipersengketakan kepemilikannya; diletakkan sita oleh pejabat yang berwenang, atau Menjadi jaminan di bank.

Pasal 43 Undang-Undang No. 2 Tahun 2012 menetapkan bahwa pada saat pelaksanaan pemberian ganti kerugian dan pelepasan hak telah dilaksanakan atau pemberian ganti kerugian sudah dititipkan di pengadilan negeri, kepemilikan atau hak atas tanah dari pihak yang berhak menjadi hapus dan alat bukti haknya dinyatakan tidak berlaku dan tanahnya menjadi tanah yang dikuasai langsung oleh negara. Kalau setelah ganti kerugian dititipkan di pengadilan negeri oleh instansi yang memerlukan tanah berakibat kepemilikan atau hak atas tanah dari pihak yang berhak menjadi hapus dan alat bukti haknya dinyatakan tidak berlaku dan tanahnya menjadi tanah yang dikuasai langsung oleh negara, maka penitipan ganti kerugian di pengadilan negeri merupakan hapusnya hak atas tanah.

\section{Eksistensi Undang-Undang No. 20 Tahun 1961 Dengan Disahkannya Undang-Undang No. 2 Tahun 2012}

Ketentuan-ketentuan pencabutan hak atas tanah yang dimuat dalam Undang-Undang No. 20 Tahun 1961, adalah: a. Undang-Undang No. 20 Tahun 1961 merupakan pelaksanaan dari ketentuan Pasal 18 Undang-Undang No. 5 Tahun 1960, yang mengatur perolehan tanah untuk kepentingan umum melalui pencabutan hak atas tanah; b. Undang-Undang No. 
20 Tahun 1961 merupakan implementasi dari asas semua hak atas tanah mempunyai fungsi sosial sebagaimana ditetapkan dalam Pasal 6 UndangUndang No. 5 Tahun 1960; c. Undang-Undang No. 20 Tahun 1961 merupakan pelaksanaan dari ketentuan Pasal 27 huruf a angka 1, Pasal 34 huruf d, dan Pasal 40 huruf d Undang-Undang No. 5 Tahun 1960 yang menetapkan Hak Milik, Hak Guna Usaha, dan Hak Guna Bangunan hapus karena pencabutan hak atas tanah; d. Hak-hak atas tanah dapat dicabut untuk kepentingan umum dengan pemberian ganti kerugian yang layak; e. Ruang lingkup kepentingan umum meliputi kepentingan bangsa dan negara, kepentingan bersama dari rakyat, dan kepentingan kepentingan pembangunan; f. Bentuk-bentuk kegiatan pembangunan yang mempunyai sifat kepentingan umum ada 13 (tiga belas) bidang; g. Pihak yang dapat mengajukan permohonan pencabutan hak atas tanah adalah instansi-instansi Pemerintah/badan-badan Pemerintah dan usaha swasta (perusahaan swasta); h. Permohonan pencabutan hak atas tanah diajukan oleh pemohon kepada Presiden Republik Indonesia dengan perantaraan Menteri Agraria melalui Kepala Inspeksi Agraria (sekarang Kepala Kantor Wilayah Badan Pertanahan Nasional Provinsi); i. Dalam pencabutan hak atas tanah, Kepala Inspeksi Agraria (sekarang Kepala Kantor Wilayah Badan Pertanahan Nasional Provinsi) meminta kepada Kepala Daerah yang bersangkutan untuk memberi pertimbangan mengenai permintaan pencabutan hak atas tanah tersebut. Khusunya bahwa untuk kepentingan umum harus dilakukan pencabutan hak atas tanah dan tentang penampungan bagi orang-orang yang terkena pencabutan hak atas tanah; j. Pejabat yang berwenang melakukan pencabutan hak atas tanah adalah Presiden Republik Indonesia; k. Pencabutan hak atas tanah ditetapkan dengan Keputusan Presiden Republik Indonesia; 1. Sebelum pencabutan hak atas tanah, Presiden Republik Indonesia mendengar masukan atau pertimbangan dari Menteri Agraria, Menteri Kehakiman, dan Menteri yang bersangkutan dengan kegiatan pemohon pencabutan hak atas tanah; m. Dalam Keputusan Presiden Republik Indonesia tentang pencabutan hak atas tanah ditetapkan subjek hak atas tanah dan objek hak atas tanah yang dicabut beserta besarnya ganti kerugian atas hak atas tanah, bangunan, tanaman, dan/atau benda-benda lain di atas tanah; $\mathrm{n}$. Besarnya ganti kerugian atas hak atas tanah, bangunan, tanaman, dan/atau benda-benda lain di atas tanah ditaksir oleh Panitia Penaksir; o. Keputusan Presiden Republik Indonesia tentang pencabutan hak atas tanah diumumkan dalam Berita Negara Republik Indonesia dan turunannya disampaikan kepada yang berhak atas hak atas tanah, bangunan, tanaman, dan/ atau benda-benda lain di atas tanah yang dicabut atas biaya pemohon pencabutan hak atas tanah; p. Jika yang berhak atas hak atas tanah, bangunan, tanaman, dan/atau benda-benda lain di atas tanah yang dicabut itu tidak bersedia menerima besarnya ganti kerugian sebagaimana ditetapkan dalam Keputusan Presiden Republik Indonesia tentang pencabutan hak atas tanah karena besarnya dianggap tidak layak, maka yang bersangkutan dapat mengajukan upaya banding kepada Pengadilan Tinggi setempat dengan maksud agar Pengadilan Tinggi memberikan putusan besarnya ganti kerugian yang layak. Putusan ganti kerugian merupakan putusan dalam tingkat yang pertama dan terakhir; q. Penyelesaian sengketa besarnya ganti kerugian dalam pencabutan hak atas tanah di Pengadilan Tinggi tidak menunda pelaksanaan pencabutan hak atas tanah; r. Dengan diterbitkan Keputusan Presiden Republik Indonesia tentang pencabutan hak atas tanah, maka hak atas tanah menjadi hapus dan hak atas tanah kembali menjadi tanah negara atau tanah yang dikuasai langsung oleh negara; s. Jika telah terjadi pencabutan hak atas tanah, tetapi kemudian ternyata bahwa hak atas tanah yang telah dicabut tidak dipergunakan sesuai dengan rencana peruntukannya, yang mengharuskan dilakukannya pencabutan hak atas tanah itu, maka bekas pemegang hak yang hak atas tanahnya dicabut diberi prioritas pertama untuk mendapatkan kembali hak atas tanahnya.

Ketentuan-ketentuan tentang pengadaan tanah untuk kepentingan umum yang dimuat dalam Undang-Undang No. 2 Tahun 2012 dan dilaksanakan oleh Peraturan Presiden Republik Indonesia No. 148 Tahun 2015, adalah: a. Undang-Undang No. 2 Tahun 2012 merupakan pelaksanaan dari ketentuan Pasal 18 Undang-Undang No. 5 Tahun 1960, yang mengatur perolehan tanah untuk kepentingan umum; b. UndangUndang No. 2 Tahun 2012 merupakan implementasi dari asas semua hak atas tanah mempunyai fungsi sosial sebagaimana ditetapkan dalam Pasal 6 UndangUndang No. 5 Tahun 1960; c. Undang-Undang No. 2 Tahun 2012 merupakan pelaksanaan dari ketentuan 
Pasal 27 huruf a angka 2, Pasal 34 huruf c, dan Pasal 40 huruf c Undang-Undang No. 5 Tahun 1960 yang menetapkan Hak Milik, Hak Guna Usaha, dan Hak Guna Bangunan hapus karena pelepasan hak atas tanah; d. Undang-Undang No. 2 Tahun 2012 mengatur pengadaan tanah bagi pelaksanaan pembangunan untuk kepentingan umum atau pengadaan tanah untuk kepentingan umum; e. Undang-Undang No. 2 Tahun 2012 memberikan pengertian pengadaan tanah, yaitu kegiatan menyediakan tanah dengan cara memberikan ganti kerugian yang layak dan adil kepada pihak yang berhak; f. Pihak yang memerlukan tanah dalam pengadaan tanah untuk kepentingan umum adalah instansi; g. UndangUndang No. 2 Tahun 2012 mengatur pengadaan tanah yang diorientasikan untuk kepentingan umum; h. Bidang kegiatan pembangunan yang termasuk kepentingan umum ada 18 (delapan belas) macam; i. Pengadaan tanah untuk kepentingan umum diselenggarakan sesuai dengan Rencana Tata Ruang Wilayah, Rencana Pembangunan Nasional/Daerah, Rencana Strategis, dan Rencana Kerja setiap instansi yang memerlukan tanah. Dalam hal pengadaan tanah dilakukan untuk infrastruktur minyak, gas, dan panas bumi, pengadaannya diselenggarakan berdasarkan Rencana Strategis dan Rencana Kerja setiap instansi yang memerlukan tanah; j. Pengadaan tanah untuk kepentingan umum dilaksanakan oleh Pelaksana Pengadaan Tanah; k. Objek pengadaan tanah untuk kepentingan umum adalah tanah, ruang atas tanah dan bawah tanah, bangunan, tanaman, benda yang berkaitan dengan tanah, atau lainnya yang dapat dinilai; 1. Dalam pengadaan tanah untuk kepentingan umum diberikan ganti kerugian kepada pihak yang berhak; m. Benda-benda yang diberikan ganti kerugian adalah tanah, ruang atas tanah dan bawah tanah, bangunan, tanaman, dan benda yang berkaitan dengan tanah; $n$. Pemberian ganti kerugian dapat diberikan dalam pengadaan tanah untuk kepentingan umum berbentuk uang, tanah pengganti, permukiman kembali, kepemilikan saham; atau bentuk lain yang disetujui oleh kedua belah pihak; o. Pihak yang berhak sebagai penerima ganti kerugian dalam pengadaan tanah untuk kepentingan umum, adalah pemegang hak atas tanah, pemegang Hak Pengelolaan, nadzir untuk tanah wakaf, pemilik tanah bekas milik adat, masyarakat hukum, pihak yang menguasai tanah negara dengan itikad baik, pemegang dasar penguasaan atas tanah, dan pemilik bangunan, tanaman atau benda lain yang berkaitan dengan tanah; p. Penetapan besarnya ganti kerugian dalam pengadaan tanah untuk kepentingan umum dilakukan oleh Penilai Pertanahan; q. Cara perolehan tanah dalam pengadaan tanah untuk kepentingan umum ditempuh melalui pelepasan hak oleh pihak yang berhak; r. Pelaksanaan perolehan tanah dalam pengadaan tanah untuk kepentingan umum didahului oleh musyawarah antara Pelaksana Pengadaan Tanah dengan pihak yang berhak untuk menetapkan bentuk dan besarnya ganti kerugian; s. Dalam musyawarah dapat menghasilkan kesepakatan antara Pelaksana Pengadaan Tanah dengan pihak yang berhak mengenai bentuk dan besarnya ganti kerugian. Hasil kesepakatan dalam musyawarah menjadi dasar pemberian ganti kerugian kepada pihak yang berhak yang dituangkan dalam berita acara kesepakatan; $t$. Pada saat pelaksanaan pemberian ganti kerugian dan pelepasan hak telah dilaksanakan, kepemilikan atau hak atas tanah dari pihak yang berhak menjadi hapus dan alat bukti haknya dinyatakan tidak berlaku dan tanahnya menjadi tanah yang dikuasai langsung oleh negara; u. Dalam hal musyawarah antara antara Pelaksana Pengadaan Tanah dengan pihak yang berhak untuk menetapkan bentuk dan besarnya ganti kerugian tidak mencapai kesepakatan, yaitu pihak yang berhak tidak menyetujui besarnya ganti kerugian yang ditetapkan oleh Pelaksana Pengadaan Tanah, maka pihak yang berhak dapat mengajukan keberatan kepada pengadilan negeri setempat dalam waktu paling lama 14 (empat belas) hari kerja setelah musyawarah penetapan ganti kerugian. Pengadilan negeri memutus bentuk dan/atau besarnya ganti kerugian dalam waktu paling lama 30 (tiga puluh) hari kerja sejak diterimanya pengajuan keberatan. Pihak yang keberatan terhadap putusan pengadilan negeri dalam waktu paling lama 14 (empat belas) hari kerja dapat mengajukan kasasi kepada Mahkamah Agung Republik Indonesia. Mahkamah Agung Republik Indonesia memberi putusan dalam waktu paling lama 30 (tiga puluh) hari kerja sejak permohonan kasasi diterima. Putusan pengadilan negeri/Mahkamah Agung Republik Indonesia yang telah memperoleh kekuatan hukum tetap menjadi dasar pembayaran ganti kerugian kepada pihak yang mengajukan keberatan; v. Pada saat pelaksanaan pemberian ganti kerugian dan pelepasan hak telah 
dilaksanakan atau pemberian ganti kerugian sudah dititipkan di pengadilan negeri, kepemilikan atau hak atas tanah dari pihak yang berhak menjadi hapus dan alat bukti haknya dinyatakan tidak berlaku dan tanahnya menjadi tanah yang dikuasai langsung oleh negara.

Ada kesamaan pengaturan antara UndangUndang No. 20 Tahun 1961 tentang Pencabutan Hak Atas Tanah, dan Undang-Undang No. 2 Tahun 2012 tentang Pengadaan Tanah Untuk Kepentingan Umum, yaitu: a. pencabutan hak atas tanah dan pengadaan tanah untuk kepentingan umum mengatur perolehan tanah untuk kepentingan umum; b. pencabutan hak atas tanah dan pengadaan tanah untuk kepentingan umum mengatur hapusnya hak atas tanah yang berakibat hak atas tanah kembali menjadi tanah negara atau tanah yang dikuasai langsung oleh negara; c. Pihak yang memerlukan tanah dalam pencabutan hak atas tanah dan pengadaan tanah untuk kepentingan umum adalah instansi; d. Adanya pemberian ganti kerugian yang layak atas hak atas tanah, bangunan, tanaman, dan/atau benda-benda lain yang berkaitan dengan tanah; e. Pihak yang memperoleh ganti kerugian dalam pencabutan hak atas tanah dan pengadaan tanah untuk kepentingan umum adalah pemegang hak atas tanah; f. Adanya lembaga yang menaksir besarnya ganti kerugian atas hak atas tanah, bangunan, tanaman, dan/atau bendabenda lain yang berkaitan dengan tanah; g. Adanya upaya keberatan dari pihak yang memperoleh ganti kerugian atas besarnya ganti kerugian yang dinilai tidak layak. Dalam pencabutan hak atas tanah, bentuk keberatannya berupa mengajukan upaya banding ke Pengadilan Tinggi setempat, sedangkan dalam pengadaan tanah untuk kepentingan umum, bentuk keberatannya berupa mengajukan upaya keberatan ke Pengadilan Negeri setempat.

Undang-Undang No. 2 Tahun 2012 diundangkan tidak dengan maksud mencabut atau menyatakan tidak berlaku Undang-Undang No. 20 Tahun 1961 walaupun mengatur hal yang sama tentang perolehan tanah untuk kepentingan umum. Dalam pelaksanaan perolehan tanah untuk kepentingan umum, yang digunakan sebagai pedoman adalah Undang-Undang No. 2 Tahun 2012 bukan UndangUndang No. 20 Tahun 1961. Upaya pengesampingan Undang-Undang No. 20 Tahun 1961 oleh UndangUndang No. 2 Tahun 2012 dalam perolehan tanah untuk kepentingan umum adalah menggunakan asas Undang-Undang yang baru mengesampingkan atau meniadakan Undang-Undang yang lama, yang mengatur materi yang sama. Asas ini dikemukakan oleh Hartono Hadisoeprapto, yaitu Lex posteriori derogat lex posteriori, yaitu undang-undang yang baru mengubah atau meniadakan undang-undang yang lama, yang mengatur materi yang sama. ${ }^{14}$ Berdasarkan asas ini, dalam perolehan tanah untuk kepentingan umum menggunakan Undang-Undang No. 2 Tahun 2012 sebagai aturan hukumnya daripada Undang-Undang No. 20 Tahun 1961. Secara normatif, Undang-Undang No. 20 Tahun 1961 masih berlaku disebabkan belum dicabut atau dinyatakan tidak berlaku oleh undang-undang yang baru. Namun demikian, secara empiris, Undang-Undang No. 20 Tahun 1961 tidak dipergunakan disebabkan sudah ada Undang-Undang No. 2 Tahun 2012.

\section{PENUTUP \\ Kesimpulan}

Ada dua undang-undang yang mengatur perolehan tanah untuk kepentingan umum oleh instansi, yaitu Undang-Undang No. 20 Tahun 1961 tentang Pencabutan Hak Atas Tanah, dan UndangUndang No. 2 Tahun 2012 tentang Pengadaan Tanah Untuk Kepentingan Umum.

Pencabutan hak atas tanah dan pengadaan tanah untuk kepentingan umum merupakan faktor penyebab hapusnya hak atas tanah dan berakibat hak atas tanah kembali menjadi tanah negara atau tanah yang dikuasai langsung oleh negara. Hapusnya hak atas tanah karena pencabutan hak atas tanah melalui penerbitan Surat Keputusan Presiden Republik Indonesia, sedangkan hapusnya hak atas tanah karena pengadaan tanah untuk kepentingan umum melalui pelepasan hak atas tanah.

Dalam perolehan tanah untuk kepentingan umum menggunakan Undang-Undang No. 2 Tahun 2012 sebagai aturan hukumnya bukan menggunakan Undang-Undang No. 20 Tahun 1961. Secara normatif, Undang-Undang No. 20 Tahun 1961 masih berlaku disebabkan belum dicabut atau dinyatakan tidak berlaku oleh Undang-Undang yang baru. Namun demikian, secara empiris, Undang-Undang No. 20

${ }^{14}$ Hartono Hadisoeprapto, Pengantar Hukum Indonesia, Liberty, Yogyakarta, 1982, h. 30. 
Tahun 1961 tidak dipergunakan disebabkan sudah ada Undang-Undang No. 2 Tahun 2012.

\section{Rekomendasi}

Pengadaan tanah untuk kepentingan pembangunan sebaiknya menggunakan UU No. 2 Tahun 2012 karena pengaturan pengadaan tanah untuk kepentingan pembangunan sesuai dengan kondisi saat ini.

\section{DAFTAR PUSTAKA}

\section{Peraturan Perundang-undangan:}

Undang-Undang Nomor 5 Tahun 1960 tentang Peraturan Dasar Pokok-poko Agraria.

Undang-Undang Nomor 20 Tahun 1961 tentang Pencabutan Hak-hak Atas Tanah dan Bendabenda Yang Ada di Atasnya.

Undang-Undang Nomor 2 Tahun 2012 tentang Pengadaan Tanah Bagi Pelaksanaan Pembangunan Untuk Kepentingan Umum.

Peraturan Presiden Nomor 148 Tahun 2015 tentang Perubahan Keempat Peraturan Presiden Nomor 71 Tahun 2012 tentang Penyelenggaraan Pengadaan Tanah Bagi Pelaksanaan Pembangunan Untuk Kepentingan Umum.

\section{Buku:}

Abdurrahman, 1996, Masalah-masalah Pencabutan Hak Atas Tanah dan Pengadaan Tanah Bagi Pelaksanaan Pembangunan Untuk Kepentingan Umum, Bandung: Citra Aditya Bakti.

Hadisoeprapto, Hartono, 1982, Pengantar Hukum Indonesia, Yogyakarta: Liberty.
Hutagalung, Arie S., 2002, Serba Aneka Masalah Tanah Dalam Kegiatan Ekonomi, Jakarta: Badan Penerbit Fakultas Hukum Universitas Indonesia. Salle, Aminuddin, 2007, Hukum Pengadaan Tanah Untuk Kepentingan Umum, Yogyakarta: Kreasi Total Media.

Santoso, Urip, 2013, Hukum Pengadaan Tanah Untuk Kepentingan Umum, Surabaya: Airlangga University Press.

2014, Hukum Agraria Kajian Komprehensif, Jakarta: Kencana Prenada Media.

Soeprapto, R., 1986, Undang-Undang Pokok Agraria Dalam Praktek, Jakarta: Universitas Indonesia Press.

\section{Jurnal:}

Eman, "Aspek Kepentingan Umum Dalam Pencabutan Hak Atas Tanah Setelah Berlakunya Keputusan Presiden Republik Indonesia No. 55 Tahun 1993", Majalah Yuridika, No. 1 Tahun XI, Fakultas Hukum Universitas Airlangga, JanuariFebruari 1996.

Harsono, Boedi, “Aspek Yuridis Penyediaan Tanah", Majalah Hukum dan Pembangunan, Nomor 2 Tahun XX, Fakultas Hukum Universitas Indonesia, Jakarta, April 1990.

\section{Makalah:}

Nurlinda, Ida, "Penyelesaian Sengketa dan/atau Konflik Dalam Pengadaan Tanah Untuk Kepentingan Umum", Makalah, Seminar Nasional Pengadaan Tanah Untuk Kepentingan Umum Pasca Berlakunya Undang-Undang No. 2 Tahun 2012, Program Pascasarjana Universitas Airlangga, Surabaya, 27 September 2012. 